\title{
IbM PENGEMBANGAN PRODUK BERBASIS LELE DENGAN KONSEP ZERO WASTE PROCESS DI KELURAHAN SUNGAI JAWI KECAMATAN PONTIANAK KOTA, KOTA PONTIANAK
}

\author{
IbM Based Product Development With Catfish Concept Zero Waste Process In The \\ Village Of River Jawi Pontianak City District, City Pontianak
}

\author{
Nani Nuraenah $^{1)}$, Kristina Novalina ${ }^{1)}$, Ika Meidy Deviarni ${ }^{1)}$ \\ Dosen Program Studi Teknologi Pengolahan Hasil Perikanan, Politeknik Negeri Pontianak ${ }^{1)}$ \\ Email: naninuraenah@ymail.com; sandy.novalin@yahoo.com; ikameidy@gmail.com
}

\begin{abstract}
Catfish is a freshwater fish that is preferred by the people in Indonesia, including the people in Pontianak, West Kalimantan. The high consumption of catfish led to the proliferation of catfish farming in West Kalimantan, one of them in the region of Lake Sentarum Sungai Jawi, Pontianak. It is often complained by catfish farmers are profit from the sale of fresh catfish is relatively small given the high production costs, especially feed costs and lower selling prices of catfish when the harvest season arrives. Efforts should be made to help the development of catfish farming is to develop products based processing catfish as a business companion. In the form of processed products lele expected sale value of catfish can be improved, even at harvest time though. The general objective of the implementation of this community services activity is the creation of a business-based processed products lele with the concept of cleaner production as a companion catfish farming. The method applied in this activity consists of: demonstration manufacture products nuggets, bone chips and bark chips catfish; kuisoner; and investment products catfish processing tools. Indicators of success of implementation of activities community services is based on achievement of outcomes is understanding partner of the training materials, skills partners in catfish processing into products, the availability of adequate means of production, and interest partners to establish business catfish processed products. The results obtained from this activity is $100 \%$ working partners increase their knowledge and skills in the meat processing catfish into the product nuggets, fish bones into a cracker fish bones and skin of fish into bark chips and partners are willing to build a business processing these catfish and that such efforts have been supported by adequate production equipment.
\end{abstract}

Keywords: nuggets, bone chips, bark chips, catfish, businesses

\begin{abstract}
ABSTRAK
Ikan lele merupakan salah satu jenis ikan air tawar yang cukup diminati oleh masyarakat di Indonesia, termasuk masyarakat di Pontianak, Kalimantan Barat (Kalbar). Tingginya konsumsi ikan lele menyebabkan menjamurnya budidaya lele di Kalbar, salah satunya di wilayah Danau Sentarum Kelurahan Sungai Jawi, Kota Pontianak. Hal yang sering dikeluhkan oleh pembudidaya lele adalah keuntungan hasil penjualan lele segar yang relatif kecil mengingat tingginya biaya produksi khususnya biaya pakan dan turunnya harga jual lele ketika musim panen raya tiba. Upaya yang dapat dilakukan untuk membantu pengembangan usaha budidaya ikan lele tersebut adalah dengan mengembangkan produk-produk pengolahan berbasis lele sebagai usaha pendamping. Dalam bentuk produk olahan lele diharapkan nilai jual ikan lele dapat ditingkatkan, bahkan pada saat panen raya sekalipun. Tujuan umum dilaksanakannya kegiatan PKM ini adalah terbentuknya usaha produk olahan berbasis lele
\end{abstract}


dengan konsep produksi bersih sebagai pendamping usaha budidaya lele. Metode yang diterapkan dalam kegiatan ini terdiri dari: demontrasi pembuatan produk nugget, kerupuk tulang, dan keripik kulit lele; kuisoner; dan investasi alat pengolahan produk lele. Indikator keberhasilan terlaksananya kegiatan Pengabdian Kepada Masyarakat (PKM) didasarkan pada tercapainya luaran berupa pemahaman mitra terhadap materi pelatihan, keterampilan mitra kerja dalam mengolah lele menjadi produk, ketersediaan alat produksi yang memadai, dan minat mitra kerja untuk membentuk usaha produk olahan lele. Hasil yang diperoleh dari kegiatan ini adalah $100 \%$ mitra kerja bertambah pengetahuan dan keterampilan dalam mengolah daging lele menjadi produk nugget, tulang ikan menjadi kerupuk tulang ikan, dan kulit ikan menjadi keripik kulit dan mitra kerja berminat untuk membentuk usaha olahan lele tersebut dan usaha tersebut sudah didukung dengan peralatan produksi yang memadai.

Kata kunci : nugget, kerupuk tulang, keripik kulit, lele, usaha

\section{PENDAHULUAN}

Ikan lele merupakan salah satu jenis ikan air tawar yang cukup diminati oleh masyarakat di Indonesia, termasuk masyarakat di Pontianak, Kalimantan Barat (Kalbar). Ikan ini disukai tidak hanya karena rasa dagingnya yang gurih dan bergizi, tetapi juga harganya relatif murah sehingga terjangkau oleh setiap lapisan masyarakat. Selain itu, ikan ini pun cukup mudah untuk dibudidayakan. Hal ini terkait daya hidup ikan lele yang tinggi bahkan di air yang keruh dan berlumpur sekalipun. Selain itu, ikan lele juga memiliki pertumbuhannya relatif cepat, mudah dikembangbiakkan, dan dapat dibudidayakan di lahan sempit (Ghufron dan Kordi 2010). Hal tersebut menyebabkan banyak orang tertarik untuk membudidayakan ikan lele.

Salah satu lokasi budidaya lele di Kota Pontianak (Propinsi Kalimantan Barat) adalah di wilayah Danau Sentarum Kelurahan Sungai Jawi, Kota Pontianak. Kapasitas produksi lele di wilayah ini mencapai $200 \mathrm{~kg} / \mathrm{siklus} \mathrm{produksi.} \mathrm{Dalam} \mathrm{hal}$ pemasaran ikan lele segar tidak ditemui hambatan berarti karena ikan lele cukup diminati oleh masyarakat Pontianak. Hal yang sering dikeluhkan oleh pembudidaya lele adalah keuntungan hasil penjualan lele segar yang relatif kecil mengingat tingginya biaya produksi khususnya biaya pakan dan turunnya harga jual lele ketika musim panen raya tiba.
Upaya yang dapat dilakukan untuk membantu pengembangan usaha budidaya ikan lele tersebut adalah dengan mengembangkan produk-produk pengolahan berbasis lele sebagai usaha pendamping. Dalam bentuk produk olahan lele diharapkan nilai jual ikan lele dapat ditingkatkan, bahkan pada saat panen raya sekalipun. Untuk memaksimalkan pengembangan produk olahan lele tersebut dapat dibentuk usaha dengan konsep proses produksi bersih (zero waste process). Dengan proses produksi bersih, seluruh bagian ikan mulai dari daging, kulit, dan tulang dimanfaatkan menjadi berbagai jenis produk. Dengan teknik ini, diharapkan proses produksi lebih ramah lingkungan karena tidak meninggalkan limbah dan nilai ekonomis usaha juga meningkat.

Peluang usaha produk olahan berbasis ikan lele masih sangat terbuka untuk dikembangkan khususnya di Kalimantan Barat. Hal ini dikarenakan ikan lele umumnya dijual dalam bentuk segar atau digoreng (seperti pecel lele) dan hampir tidak dijumpai produk penganan berbasis lele. Kondisi ini terjadi dikarenakan pembudidaya lele masih belum mengenal teknologi pengolahan ikan.

Kegiatan Pengabdian Kepada Masyarakat (PKM) ini perlu dilaksanakan dengan maksud untuk mentranfer teknologi tepat guna khususnya dalam bidang pengolahan hasil perikanan sehingga masyarakat pembudidaya lele memiliki kemampuan dalam mengolah ikan lele 
menjadi berbagai produk diversifikasi yang bernilai tambah dan berdaya jual tinggi. Pada kegiatan PKM ini, jenis olahan lele yang akan dikembangkan adalah nugget lele, keripik kulit ikan, dan kerupuk tulang ikan.

Nugget merupakan salah satu makanan yang tidak asing lagi bagi masyarakat termasuk di kota Pontianak. Menurut Elingosa (1994), nugget adalah suatu bentuk produk daging giling yang telah dibumbui, kemudian diselimuti oleh perekat tepung dan dilumuri tepung roti, digoreng setengah matang lalu dibekukan untuk mempertahankan mutu selama penyimpanan. Namun demikian, pada umumnnya bahan utama nugget adalah daging sapi atau daging ayam. Olahan nugget berbahan baku ikan sangat jarang dijumpai di pasaran sehingga produk nugget lele memiliki peluang cukup besar untuk dikembangkan. Sedangkan untuk produk kerupuk umumnya terbuat dari campuran daging ikan dan tepung. Jenis kerupuk yang terbuat tulang ikan belum ada dipasaran sehingga jenis produk tersebut juga berpotensi untuk dikembangkan sebagai suatu usaha. Selain itu tingginya kandungan mineral pada tulang ikan, khususnya kalsium dan fosfor dengan nilai berturut-turut 43 $\mathrm{mg} / 100 \mathrm{~g}$ dan $116 \mathrm{mg} / 100 \mathrm{gr}$ (Suprapti 2001) juga menjadi nilai tambah bagi kerupuk tulang ikan yang dihasilkan. Limbah kulit ikan yang biasanya tidak dikonsumsi, dapat diolah menjadi produk yang bergizi yaitu berupa keripik kulit ikan.

Pengembangan usaha olahan lele ini selain berpotensi sebagai suatu usaha yang menguntungkan, disisi lain juga dapat memberikan dampak positif lebih lagi bagi peningkatan perekonomian masyarakat sekitar. Pertama, usaha olahan lele membuka peluang kerja bagi masyarakat sekitar, khususnya bagi para ibu yang umumnya berprofesi sebagai ibu rumah tangga. Kedua, tingkat kesejahteraan masyarakat sekitar akan meningkat. Ketiga, selain memberi inspirasi, kehadiran kelompok usaha pembudidaya dan pengolahan produk berbasis lele ini juga diharapkan akan mendorong masyarakat sekitar untuk tergerak belajar mengenai wirausaha lebih lagi.

\section{BAHAN DAN METODE}

Lingkup kegiatan PKM meliputi: persiapan tim pelaksana; koordinasi dengan mitra kerja; pelaksanaan kegiatan pelatihan pembuatan produk olahan lele (nugget, kerupuk tulang ikan, dan keripik kulit ikan) disertai dengan penyampaian materi-materi terkait sanitasi dan higienis makanan, pengenalan sistem pemasaran secara online, analisis usaha olahan berbasis lele, dan perizinanan PIRT; dan penguatan modal usaha melalui pengadaan alat produksi.

\section{Bahan}

Bahan untuk pembuatan nugget meliputi: ikan lele, tepung tapioka, tepung terigu, garam, penyedap rasa, lada halus, telur, margarin, bawang bombay, bawang putih, dan tepung susu. Bahan pembuatan kerupuk tulang ikan meliputi: daging lele, tulang ikan, soda kue, tepung tapioka, telur, garam, penyedap, dan bawang putih. Sedangkan bahan untuk keripik kulit ikan meliputi: tepung tapioka, kulit ikan, ketumbar, garam, penyedap, dan bawang putih.

\section{Alat}

lat-alat yang digunakan terdiri dari: pisau, talenan, baskom, timbangan, loyang, dandang, penggiling daging, piring, sendok, kompor, blender, panci bertekanan/pressure cooker, alat pemotong kerupuk, dan vacuum packaging.

\section{Pengumpulan data dan analisis data}

Target luaran yang ingin dicapai dalam kegiatan ini adalah keterampilan mitra kerja dalam pembuatan produk olahan berbasis lele, pemahaman mitra kerja terhadap materi-materi pelatihan, kecukupan tersedianya alat-alat produksi, dan minat terhadap keberlanjutan usaha produk olahan lele. Pengumpulan data dilakukan melalui pengisian kusioner sebelum dan sesudah pelaksanaan kegiatan pelatihan. Kuisoner 
sebelum pelaksanaan pelatihan ditujukan untuk mengetahui profil dari mitra kerja yang meliputi status sosial, pendidikan, penghasilan, dan pengetahuan awal mitra kerja seputar olahan lele. Sedangkan kuisioner yang diisi setelah kegiatan ditujukan untuk menilai tingkat pemahaman dan keterampilan mitra dalam pembuatan produk olahan lele serta menilai sejauh mana minat mitra untuk membuka usaha produk olahan lele.

\section{HASIL DAN PEMBAHASAN}

\section{Profil Mitra kerja}

Mitra kerja yang terlibat dalam kegiatan ini adalah ibu-ibu yang tinggal di wilayah Danau Sentarum Kelurahan Sungai Jawi, Kota Pontianak yang berjumlah 19 orang. Usia mitra bervariasi dengan rincian, usia <20 tahun (16\%), 20-30 tahun (16), 3040 tahun (47\%), dan >40 tahun (21\%). Sedangkan dari segi tingkat pendidikan, 53\% mitra kerja berpendidikan setingkat SD, sebagian kecil tamat SMP (21\%), sisanya tamat SMA (16\%) dan tidak sekolah (11\%). Sebagian besar mitra adalah ibu rumah tangga (58\%), belum bekerja (5\%), pelajar/mahasiswa $(11 \%)$, dan lainnya (pedagang, pemulung) sekitar 26\%. Dari segi penghasilan, mitra sebagian besar berpenghasilan $<1$ juta/bulan (79\%), dan lainnya $>5$ juta/bulan (16\%), antara 1 juta2,5 juta $(5 \%)$.

Berdasarkan hal tersebut, dapat dilihat bahwa sebagian besar mitra yang terlibat masih tergolong kategori usia produktif, berpendidikan menengah, dan berpenghasilan kecil sehingga diharapkan mitra memiliki keinginan besar untuk keberlanjutan dari kegiatan yang dilakukan dengan harapan bisa memperbaiki taraf hidup dan penghasilan keluarga.

\section{Tingkat pengetahuan awal mitra mengenai olahan lele}

Penggalian informasi mengenai wawasan mitra kerja seputar olahan lele sangat diperlukan untuk mengetahui sejauh mana mitra mengenal atau memahami tentang produk maupun proses pengolahan olahan lele khususnya produk nugget lele, kerupuk tulang lele, dan keripik kulit lele. Informasi yang diperoleh dapat digunakan sebagai indikator keberhasilan kegiatan dengan membandingkan antara wawasan mitra sebelum dan sesudah mengikuti kegiatan PKM. Penggalian informasi wawasan mitra dilakukan dengan membagikan kuisoner sebelum pelaksanaan kegiatan pelatihan. Kuisoner tersebut berisi pertanyaan seputar olahan nugget, kerupuk tulang, dan keripik kulit lele. Hasil penggalian wawasan mitra kerja seputar olahan lele dapat dilihat pada Tabel 1.

Tabel 1. Wawasan awal mitra kerja tentang olahan lele

\begin{tabular}{lccc}
\hline \multirow{1}{*}{ Jenis olahan } & \multicolumn{3}{c}{ wawasan mitra } \\
\cline { 2 - 4 } & tahu & tidak tahu & jumlah \\
\hline $\begin{array}{l}\text { Olahan daging lele } \\
\text { menjadi nugget }\end{array}$ & 11 & 8 & 19 \\
\hline & $58 \%$ & $42 \%$ & 19 \\
\hline $\begin{array}{l}\text { Olahan tulang lele } \\
\text { menjadi kerupuk }\end{array}$ & 3 & 16 & 19 \\
\hline $\begin{array}{l}\text { Olahan kulit lele menjadi } \\
\text { keripik }\end{array}$ & 2 & $84 \%$ & \\
\hline & $11 \%$ & 17 & \\
\hline
\end{tabular}


Berdasarkan Tabel 1, sebagian besar mitra sudah mengetahui tentang produk nugget namun untuk produk kerupuk tulang lele dan keripik kulit lele lebih dari $80 \%$ mitra belum mengenal produk tersebut dan belum pernah melakukan pengolahan produk tersebut. Hal ini menunjukkan bahwa sebagian besar masyarakat di daerah danau sentarum belum mengenal produk-produk olahan dari limbah hasil perikanan (dalam hal ini pemanfaatan tulang dan kulit ikan). Hal ini tentunya akan menarik minat mitra untuk mengikuti keseluruhan rangkain kegiatan sehingga mereka mendapatkan pengetahuan dan ilmu baru mengenai pembuatan produk olahan lele khususnya nugget dan produk olahan limbah tulang dan kulit lele.

\section{Luaran program pengabdian kepada masyarakat}

Tujuan umum dilaksanakannya kegiatan PKM di daerah Danau Sentarum, Kelurahan Sungai Jawi, Kecamatan Pontianak kota, Kota Pontianak adalah terbentuknya usaha produk olahan berbasis lele dengan konsep produksi bersih sebagai pendamping usaha budidaya lele sehingga dapat meingkatkan harga jual lele. Indikator keberhasilan terlaksananya kegiatan Pengabdian Kepada Masyarakat (PKM) didasarkan pada tercapainya luaran dari kegiatan ini seperti dapat dilihat pada Tabel 2.

Untuk mengetahui tingkat ketercapainya setiap luaran yang diharapkan dilakukan monitoring pada akhir kegiatan. Monitoring dilakukan dengan membagikan kuisoner setelah pelaksanaan kegiatan yang berisi pertanyaan seputar pemahaman terhadap materi-materi yang diberikan, ketersediaan alat-alat produksi yang memadai, dan minat untuk membentuk usaha produk olahan lele.

Khusus untuk menilai keterampilan mitra dalam mengolah produk olahan lele dilakukan dengan melakukan pemantauan selama pelaksanaan demonstrasi dan menilai produk akhir yang dihasilkan. Hasil monitoring tingkat ketercapaian luaran kegiatan dapat dilihat pada Tabel 3 .

Tabel 2. Luaran kegiatan PKM di Danau Sentarum

\begin{tabular}{|c|c|}
\hline Kegiatan & Luaran \\
\hline $\begin{array}{l}\text { 1. Penyampaian materi pelatihan yang } \\
\text { terkait dengan proses pengolahan, } \\
\text { sanitasi dan higiene, manajemen usaha, } \\
\text { sistem pemasaran secara online, dan } \\
\text { perizinan PIRT olahan berbasis lele } \\
\text { (nugget lele, kerupuk tulang, dan } \\
\text { keripik kulit lele). }\end{array}$ & $\begin{array}{l}\text { Pemahaman mitra kerja terhadap materi } \\
\text { proses pengolahan, sanitasi dan higienis, } \\
\text { sistem pemasaran secara online, analisis } \\
\text { usaha, serta mekanisme pembuatan PIRT } \\
\text { olahan berbasis lele (nugget lele, kerupuk } \\
\text { tulang, dan keripik kulit lele). }\end{array}$ \\
\hline $\begin{array}{l}\text { 2. Demonstrasi proses pembuatan produk } \\
\text { nugget lele, kerupuk tulang lele, dan } \\
\text { keripik kulit lele. }\end{array}$ & $\begin{array}{l}\text { Keterampilan mitra kerja dalam mengolah } \\
\text { ikan lele menjadi produk nugget, kerupuk } \\
\text { tulang, dan keripik kulit lele. }\end{array}$ \\
\hline $\begin{array}{l}\text { 3. Penguatan modal pembentukan usaha } \\
\text { baru dalam bentuk bantuan alat-alat } \\
\text { produksi olahan lele }\end{array}$ & $\begin{array}{l}\text { Ketersediaan alat-alat produksi olahan } \\
\text { nugget lele, kerupuk tulang, dan keripik kulit } \\
\text { lele. }\end{array}$ \\
\hline $\begin{array}{l}\text { 4. Ketertarikan mitra kerja untuk } \\
\text { membentuk usaha olahan lele }\end{array}$ & $\begin{array}{l}\text { Minat mitra kerja untuk membentuk usaha } \\
\text { olahan nugget lele, kerupuk tulang, dan } \\
\text { keripik kulit lele }\end{array}$ \\
\hline
\end{tabular}


Berdasarkan Tabel 3, pelaksanaan kegiatan PKM pengembangan produk berbasis lele dengan konsep zero waste process di kelurahan sungai jawi kecamatan pontianak kota, Kota Pontianak behasil dilaksanakan dengan baik. Hal ini dapat dilihat dari tiga indikator yaitu minat mitra terhadap terbentuknya usaha olahan lele, ketersediaan alat-alat produksi yang memadai, dan penyampaian materi pelatihan. Semua mitra kerja yang terlibat dalam kegiatan ini menyatakan tertarik dan ingin mencoba untuk menjalani usaha pengolahan nugget, kerupuk tulang, dan keripik kulit lele. Demikian juga dengan ketersediaan alat-alat produksi yang akan digunakan untuk memperlancar proses produksi dan usaha olahan lele semua mitra yang terlibat menyatakan bahwa peralatan yang diberikan sudah memadai untuk proses produksi dan usaha produk olahan lele. Disamping itu, berdasarkan hasil pemantauan selama kegiatan demonstrasi pembuatan produk nugget lele, kerupuk tulang lele, dan keripik kulit lele, $100 \%$ mitra terampil dalam mengolah daging lele menjadi produk nugget, tulang lele menjadi kerupuk tulang, dan kulit lele menjadi keripik kulit.

Tabel 3. Monitoring akhir kegiatan

\begin{tabular}{lclclc}
\hline $\begin{array}{l}\text { Pilihan } \\
\text { jawaban }\end{array}$ & $\begin{array}{c}\text { minat usaha } \\
\text { olahan lele }\end{array}$ & $\begin{array}{l}\text { Pilihan } \\
\text { jawaban }\end{array}$ & $\begin{array}{c}\text { alat } \\
\text { produksi }\end{array}$ & $\begin{array}{l}\text { Pilihan } \\
\text { jawaban }\end{array}$ & $\begin{array}{c}\text { Kejelasan } \\
\text { materi }\end{array}$ \\
\hline $\begin{array}{l}\text { tertarik dan } \\
\text { ingin mencoba }\end{array}$ & 19 & memadai & 19 & $\begin{array}{l}\text { jelas dan } \\
\text { paham }\end{array}$ & 19 \\
\hline tidak tahu & 0 & $\begin{array}{l}\text { Belum } \\
\text { memadai }\end{array}$ & 0 & tidak tahu & 0 \\
\hline tidak tertarik & 0 & $\begin{array}{l}\text { Tidak } \\
\text { tahu }\end{array}$ & 0 & $\begin{array}{l}\text { tidak jelas } \\
\text { dan tidak } \\
\text { paham }\end{array}$ & 0 \\
\hline jumlah & 19 & & 19 & & 19 \\
\hline
\end{tabular}

\section{KESIMPULAN}

1. $100 \%$ mitra kerja bertambah pengetahuan dan keterampilan dalam mengolah daging lele menjadi produk nugget, tulang ikan menjadi kerupuk tulang ikan, dan kulit ikan menjadi keripik kulit.

2. Mitra kerja berminat untuk membentuk usaha olahan lele (nugget, kerupuk tulang, dan keripik kulit lele) dan sudah didukung dengan peralatan produksi yang memadai.

\section{DAFTAR PUSTAKA}

Elingosa, T. 1994. Pembuatan Fish Nugget dari Ikan Tenggiri. Skripsi. Jurusan Teknologi Pangan dan Gizi. Fakultas Teknologi Pertanian, IPB. Bogor.

Ghufron MH, Kordi K. 2010 Budidaya Lele di Kolam Terpal. Yogyakarta: Lily Publisher.

Suprapti. 2001. Ikan Lele Lokal (Clarias batrachus). Teknologi Budidaya. Jakarta. 